\title{
THE DYNAMICS OF THE EUROPEAN UNION REGIONAL POLICY
}

\author{
Magdalena Sitek ${ }^{1}$ \\ Alcide De Gasperi University of Euroregional Economy (Poland)
}

\begin{abstract}
The subject of this paper is to present the shape, the legal basis and the prospects for the development of the European Union regional policy. This policy assumes great importance in the face of weakening of state's structures due to the European Union bodies and decentralization of management of local affairs. The EU regional policy is a very problematic area and requires extensive studies. Thus, I confined myself to analyze the development of basis of the EU regional policy primarily through the prism of treaty law. The analysis showed a rate of development which process still continues. Despite a good legal basis, the EU regional policy still requires constant adjustment, especially when it comes to rationalizing subsidies. The passive regional policy leads to promote only the economically under developed areas. Therefore, it is necessary for the implementation of programs to support the innovation, especially in highly developed regions, which are the engine of the whole European Union economy.

KEYWORDS: regions, cohesion policy, structural programmes, innovative economy, the Regional Committee.
\end{abstract}

JEL CODE: R110, K100

\section{Introduction}

The European Union regional policy constitutes one of the most important directions of the activities that have been undertaken from the nineties of the twentieth century. The distribution of the Union assistance appropriations by means of the governments of the Member States not always has been effective as it was expected, particularly, over the area of smoothing away the economic differences, existing within the countries. The classic example is here Italy, which is divided into rich north and relatively poor south.

The subject of this work is presenting the development of regional policy in connection with the urgent problems which need solution, in the under - developed regions. We should assume the working hypothesis, that in the European Union, despite the efforts which are undertaken, the wide-ranging differentiation in development of the particular regions still exists.

The purpose of this work is to indicate the necessary measures to equalize the chances of development of the regions which are economically under - developed. For this purpose, we are going to analyze specifically, the European Union treaty law principles, to show the regional policy development and to signalize the possibilities of undertaking the new pro innovative and pro investment activities in under - developed areas.

The subject of the European Union regional policy was undertaken many times by numerous Polish and foreign scientists, among others: A. Bałaban (Bałaban, 1998: 48), J. Ciapała (Ciapała, 1998: 92), B. Woś (Woś, 2005: 21) or F. Zucca (Zucca, 2001: 15). These authors write about the European Union regions from different points of view. Among others, they deal with the political, ecological and social issues, particularly

\footnotetext{
Magdalena Sitek - Alcide De Gasperi University of Euroregional Economy In Józefów, dr. habil. Scientific interest: European law, Tourism law.

E-mail: ms@wsge.edu.pl

Tel.: +48227891903.
} 
the differences in economic development and others. Highly rarely they take the issue of creating the regional policies in the light of the treaty regulations.

In this work there is undertaken the descriptive and historical method, the purpose of it, is the presentation of the development of creating the European Union regional policy and its influence on the legal regulations. However, the most important are the treaty regulations. Therefore, the most significant issue is to analyze the development of the treaty inscriptions concerning the creation of the regional policy. There is necessary to use the functional method, due to which, it will be possible to show different solutions of the same issue by means of different instruments, performing the same function. This method allows also showing the law in practice (Tokarczyk, 1989: 145).

According to the research tasks, such issues should be added here: analysis of the development of European Union regional policy, description of its objectives, such as promoting the growth of economically backward regions and helping regions in economical or social transition. Additionally, the research tasks contain: description of human resource development, innovation as the essential impact on the regional development and treaty base of the European Union's regional policy.

\section{Development of the European Union regional policy (European Communities)}

The notion region is not clear and it contains different forms and terms typical for the European Union Member States. There can be the voivodeships (Poland), lands (Germany and Austria), departments (France), regions (Italy), regions and cultural communities (Belgium), but there can also be the other, untypical units of the territorial division, as for example the French oversea territories or the island autonomic regions (Portugal). The regional division generally has its historical origin, but also the geographical or political ones. Therefore, the regions are bigger administrative units, which have certain autonomy. According to the Charter of the European Regional Self-Government from 1991, regions have to have the elective, legislative and executive organs. Moreover, the autonomy constitutes the possibility to have at disposal the own financial measures from grants, the local payments or taxes (Sitek, 2011: 51).

The existing or creating the regions is connected with the European Union regional policy and with more and more intensive implementation of the regional policy. There are a lot of reasons of creating the regional policy. All of them have to be seen in the light of the globalization process of the international relations. The most important are the political and economic reasons (Puga, 2001: 45-51).

After the second world war, according to the idea of Alcide De Gasperi, Robert Schuman and Konrad Adenauer, there was initiated the process of building the united Europe. There were created three European communities, i.e. the Coal and Steel Community (1952-2002), the Atomic Energy Community (1957-2002) and the European Economic Community (1957-2002). The basic purpose of creating the new European order was to build the united economic area, free of any financial or administrative barriers.

However, the political issues constituted some significant reason of regionalization. The national state, which conception was initiated during the Renaissance period, brought numerous political conflicts, which were the reason of many wars. The problematic issue was, in particular, the route of boundaries, which were artificially marked out. When creating them, there was not taken into consideration the historical, social or geographical integrity, but the natural resources existing in the administrated territory. The conflicts about Lorraine and Ruhr, the regions situated on the borderland of France and Germany, are the example of that situation. According to the Potsdam and Yalta Agreement, there were lain out the areas of influence of the world-superpowers, without any arrangements with the local communities. As a consequence, there were created the boundaries for political needs, without consideration of the historical or geographical conditioning. On the borderland of Poland and, at that time, Czechoslovakia, Teschen was divided into two, while on the borderland of Poland and Germany, Zgorzelec left on Polish part and Gorlitz on the German part.

The consequences of the Second World War determined the European post-war leaders to undertake the activities towards building the new Europe. The economic development and the policy of smoothing away the chances among the member states should have been the foundation. Such the activities, at one point, did 
not bring the expected results, since the financial measures allocated to the member states were not correct. As a consequence, the European Communities governments were determined to the gradual development of regional policy.

The beginnings of community regional policy should be found in the Treaty on the European Economic Community (1957), there are some first normative bases there. In 1962 there was initiated the idea of creating the regional fund, partly from the measures for creating the European Orientation Fund and the Agricultural guarantee.

However, only just in 1969, the Commission submitted in the Council, the project of working out the regional policy. They postulated creating the permanent committee of regional development. The task of that committee was to harmonize the regional policy, and finally, creating the regional development fund. That fund was created during the meeting of the leaders of countries and Communities governments in December 1974, and it started its activity on $1^{\text {st }}$ January 1975 (Doliwa-Klepacki, 2005: 545-546). Nowadays, this is the most significant instrument of the EU common regional policy. The aim of this fund is the assistance in the economic development of the regions economically less developed (Wilson, 2000: 33).

The essential stages in the regional policy development are the Integrated Mediterranean Programmes, which were implemented in 1985, and the purpose of them was to prepare the communities to the integration with Spain and Portugal. The realization of that programme was supported on the measures from several structural funds within particular areas and regions of some new member states.

The European Single Act (1987) initiated the new stage of the regional development policy. At that time, there was announced, among others, the reform of structural funds and increasing the expenditures appointed to the regional policy. That reform was implemented in 1988. Some new purposes of the regional policy were defined. In 1992, in the Maastricht Treaty, there was created the Coherency Fund, which started its activities in 1994. The Coherency Fund is the supplementation of the structural funds and its purpose is to achieve the economic and social coherency of the Member States. The following programmes support the regional policy (Naruszewicz, 2004: 275):

- The European Regional Development Fund;

- The European Social Fund;

- The Financial Instrument Supporting the Fishery.

And the following Community initiatives:

- Interreg III;

- Urban II;

- Equal;

- Leader+.

The significant stage of the regional policy development was creating the Committee of Regions in 1994. This institution is the centre of giving opinions from their own initiative or according to the legal principles. It participates in making the decisions on regional matters, particularly concerning the social policy, the employment matters, the health and environmental protection (Roberts, 2002: 255).

\section{The regional policy purposes}

The regional policy purposes were, to a certain extent, drafted above. However, this is necessary to analyze more precisely, the purposes defined in the founding treaties and some later normative regulations of that type. There are three basic purposes of the regional policy, namely:

- Promoting the regional development of some under-developed regions, offering them the new investments;

- Supporting the regions over the economic or social transformation period;

- Development of human resources on regional level. 


\subsection{Promoting the development of the under-developed regions}

The first and basic purpose is promoting the under-developed regions. In the European Union there are 270 regions with different economic development levels and population. Among them, there are some regions which achieve over $200 \%$ of the average gross income of the European Union GDP, e.g. London, Brussels and Paris, but there are also some poor regions, as for example the Greek regions or some of them in Poland, the example is here the Warmian - Mazurian Voivodeship. In these regions the income per capita is almost five times less than in Paris.

The existing disproportion in the development of many European Union regions determines the necessity to undertake the adequate activities, not only by the governments of the Member States, but also by the European Union organs, on the basis of the subsidiarity principle. Therefore, in 1988 the European Community was divided into NTUS, that is to say Nomenclature of Territorial Units for Statistic. There are five NTUS, but for our work the most important is NTUS 2, which includes our voivodeships. Altogether, there are 271 NTUS 2, therein Poland has 16 of them, but Lithuania 1 (Gmyrek, 2000: 1).

According to the data included in the document, prepared by the Commission in November 2010, entitled the Fifth Report, about the economic, social and territorial coherency: among numerous data there was indicated that the investment into the future of Europe shows that the most significant economic development and GDP is noted down in the EU newly accepted Member States, i.e. in Poland, Lithuania, Slovakia, Czech Republic and even in Romania and Bulgaria. However, the level of the wealth of regions and countries is inversely proportional; namely, the richer regions are still in the countries of former European Union.

To realize this purpose, there are some cohesion activities undertaken, which pursue towards rebuilding the under-developed regions. The most significant is the economic cohesion, which aim is to smooth the differences in the GDP income per capita within the same country and within the whole Union. We can also say about the social cohesion. In this case we mean to smooth away the differences between the countries and regions with unemployment problems or the other social problems, therein the aging society problems. In the end, we can also say about the spatial cohesion, which means the improvement of the access to the peripheral areas by constructing the roads, motorways, airports or the other infrastructural objects (Szlachta, 2000: 45).

\subsection{The regions in economic and social transformation}

Another category of regions are these, where there are economic and social transformations. There are some regions in the European Union, where there has been the monoculture in the economic structure for ages, e.g. Silesia, situated on the borderland of three countries-nationalities: Poland, Germany and Czech Republic. That was the terrain rich of coal and different kinds of ores, therein the iron ore. In 1989 after the crash of the Communistic system in Poland and after implementing the European Union environmental protection policy, and because of some political transformations in Poland, it was obvious that the restructuring of this region will be necessary, as well as manipulation of the investments into the light and medium industry which is ecologically cleaner. The rural regions are in this group. They have the backward agriculture with the excessive employment in this sector of economy. These changes are mostly visible in small and medium companies (Mączyńska, 2001: 9).

The changes in the economic structure in former under developed regions are faster in the urbanized centers, in other words, where the road and air transport infrastructure is better developed. Whereas, the changes in rural areas are slower, since the infrastructure there, is worse. The similar process occurs in case of social transformation, in particular if it is about the decrease in unemployment. The increase of employment is noticeable in urban regions, whereas, it is only insignificant in rural areas. There is too much proportion of the society who works in agricultural sector in rural regions (Steinen, 1991: 19-31).

The regions with economic and social transformation are being temporary financed. They are situated between the convergence and competitiveness regions. The convergence regions are these, where GDP per capita does not exceed $75 \%$ of the EU-27 level, whereas, the competitiveness regions are the richest regions. 
The European Regional Development Fund and the European Social Fund give the financial support to transforming regions.

\subsection{The human resources development}

The third aim of regional policy is the human resources development. To achieve this aim it is necessary to implement the reforms of educational systems, to intensify the vocational trainings and to increase the rate of employment, taking into consideration the equal chances in the access to the labor market and stimulating the labor market to activities. There is necessary to support the high-risk groups. The European Social Fund finances this assignment.

The basis of economic development, supported on the innovative economy is education. Meanwhile, the statistic data shows quite significant differentiation in education of the Member States societies. Generally, in the European Union, in the group of people aged 25 to 64 , approximately $25 \%$ has the higher education. The biggest number of educated people is in Inner-London region, the number of people with higher education in that region, is as many as $51 \%$, and in the Belgian province Braban Wallon it is $49 \%$. The least number of people with higher education is in Portuguese Azores, only $8 \%$ and in Severozapad in Czech Republic, only $8 \%$. In Poland there is also significant differentiation, in Mazovian region it is $29 \%$, whereas in KuyavianPomeranian and Opole voivodeships only 16.2 \% (Matusiak, 2011: 1).

One of the basic Union activities, within the human resources development, is implementing the educational programme life lasting education. Basically, this assignment is introduced in the territories of individual countries, regardless of the differentiation of particular regions, what is not positive to the cohesion policy. Within the framework of European Union, the significant changes are introduced to the educational programmes already in primary schools, so that the innovativeness becomes the element of young people mentality (Kotarba-Kańczugowska, 2009: 13).

The different Union programmes support the realization of the educational development plans in regions, among others the programme "Life lasting education". The Erasmus and Leonardo da Vinci programmes are for people at the age until 30. The European Social Fund, the so-called soft programme, is the programme applied for people at other different age bracket. There is the European Adjusting to Globalization Fund, which supports the people who lost their work places because of the global business transformations. The aim of this programme is to help to find a job and to organize trainings allowing obtaining the new jobs, adjusted to the needs of changing labor market ${ }^{2}$.

In the Strategy Europe 2020, it is assumed that till 2020, there should be at least $15 \%$ of the EU citizens within the age bracket between 25-60, who takes part in everlasting education, whereas the percentage of people at the age bracket between 30-35, having the higher education, should be at least $40 \%$. There is also necessary to raise the financial expenditures not only by the Member States, but also by the self-governments of individual regions, because of the need to increase or change the citizen's qualifications. There was accepted in the Europe 2020 Strategy that the expenditures should not be lower than $3 \%$. This level of expenditures in the EU is achieved so far only in one region.

In the Amsterdam Treaty (1997) there was introduced the notion of territorial cohesion. It means that it is necessary to improve the financial involvement into the development of education in regions, to organize the trainings and other forms of increasing the skills. The purpose of such activities should be to teach people to predict changes and to know how to cope with them. It is also very important to build the united society. The investments in education should be joined with the investments in infrastructure, enterprise and innovations.

\subsection{Innovativeness as a driving force of the regional development}

The notion innovativeness is ambiguous; hence, it is quite difficult to define it univocally. It is claimed, that the first person that created the definition of the notion innovativeness was J. Schumpeter. According to

2 The fifth report on economic, social and territorial cohesion: Investments in the future of Europe 2010: 188 in http://ec.europa. eu/regional_policy/sources/docoffic/official/reports/cohesion5/pdf/5cr_pl.pdf) [15.04.2012] 
him, the innovativeness is the significant change if the function of production, e.g. through joining different elements of production. He distinguished the invention (a new scientific thought), the innovation and the imitativeness. Innovation is the internal factor, necessary to the company or region development (Schumpeter, 1986: 894). Innovativeness has the most significant meaning to the economic development. However, G. S. Altshuller claims that the innovativeness is linked with the creativity, hence, the innovativeness is manifested by the distinct organization and gathering the knowledge, perceiving the world, creating the new ideas and implementing them into practice (Altshuller, 1984: 23). Therefore, it is assumed, that the innovativeness occurs if there are applied some distinct procedures of producing the given goods and the distinct implementation into practice.

Innovativeness is first of all implemented in the companies together with researches. Where as the regions have the inspiring function. Hence, in the European Union it is emphasized to join the activities of scientific researches centers with the companies $\mathrm{B}+\mathrm{R}$. Therefore, the regions authorities should not discover innovativeness or do any new implementations, but they should animate the researches centers and companies existing in the given territory to act towards an innovative way.

The local authorities of the regions can achieve the goals of the Union innovative policy through the improvement of the former educational system and trainings of the children, youth and adults, through the development of new culture directed towards protection of the environment, tolerance and the openness to the new ideas, but the innovativeness can be achieved first of all through the advanced scientific researches connected with the creative initiative. The notion initiative contains not only the area of production and business, but mainly the service (Maczuga, 2002: 57).

The regional innovativeness should be grounded in the growth of employment in the sector of advanced technologies. Such the growth of employment is noted down mainly in the highly developed regions. The rest of the regions definitely differ from this level, which does not provide the full realization of the coherency policy. The reflection of such the condition is the new patents. In this case, also the biggest number of patents is registered in the highly developed regions. The weaker areas do not have enough proper research personnel or any funds to implement the modern technologies, which are quite expensive (Kuciński, 2010: 30). The existing differentiation of the innovative process in the European Union is visible from the perspective of the regional indicator of the innovative effectiveness.

Innovativeness brings numerous positive effects. In particular, the innovativeness through the education and trainings. It leads to the decrease of unemployment rate, mainly within the highly educated social group. The labor productivity is also improved mainly in highly developed regions. However, the development is weaker in the regions of convergence or these being in the transformation process (Woś, 2005: 52).

Therefore, the regional authorities have to do their best to base the practice on the proper preparation of the personnel at all the levels of administration and on the solid economic principles. The institutional workers, entrepreneurs and the ordinary dwellers of the regions have to accept as natural reaction to do something in the innovative way, not to repeat the same, even if they do it with the intention to do better (Drucker, 2004: 29).

In 1993 there was worked out the White Paper on Growth, Competitiveness and Employment. On the basis of this document the European Commission worked out the pilot plan of activities called the Regional Technology Plan - RTP. In December 1995 the European Commission published The Green Paper on Innovation, which was amended in1996. In 1994 the European Commission implemented The Regional Technology Plan RTP, later known as the Regional Innovation Strategy - RIS. The Regional Innovation and Technology Transfer Infrastructures and Strategies - RITTS, amended the RIS strategy. There were also worked out the regional innovative strategies, as for example the Regional Strategy of Innovativeness for the Mazovia 2005-2015 (Mahdjoubi, 1997: 5).

\subsection{The treaty bases of the European Union regional policy}

The regional policy was not the basis of the activities of the former community decision makers in Brussels. That was also visible in the treaty legislation. However, together with coping with the important 
economic issues, in other words, after the legal regulations in the treaty law, there was the time to regulate the other types of policies, also the regional policy, and to the introduction of the policy of innovativeness. Here, there is going to be presented, the issue of creating the regional policy in the treaty law in connection with the policy of innovativeness.

\subsection{The founding treaties}

There were three founding treaties, but only in one of them, in the Treaty on the European Economic Community from 1957, there is stated about the regionalism. In the preamble the signatories declared the harmonic development and the need to smooth away the differences among the particular regions, particularly if we mean the regions economically underdeveloped. The regional issue is also mentioned in case of defining the frameworks of the agricultural policy. In article 39 of the Treaty there is stated that the common agricultural policy should take into consideration the differentiations in the development of individual agricultural regions.

In turn, in article 49, where it is stated about the free flow of people, they say about the necessity to establish such the mechanisms, which will allow keeping the balance in the labor market, taking into consideration the unemployment differentiation in different regions of the Community. Some similar regulations are stated in the topic of the transport policy.

In article $75, \S 3$ there was stated about the development of transport infrastructure. The European legislator authorized the European Commission to publish the proper legal regulations, taking into consideration the level of living and employment in particular regions. In article $80, \S 2$, it was allowed to obtain the European Commission agreement to make the exception to the rule of forbidding any economic and administrative barriers in the market of transportation service, particularly financial supporting of the companies. Such the exception to the rules was possible on account of the regional underdevelopment.

In article 82 we can find the example, in which there was allowed to apply different payments in the regions economically and politically affected by the division of Germany after the Second World War. In article 92, $\$ 3$ there are some regulations allowing the state financial support to the companies. Such kind of help was allowed to support the economic development of the regions with the low living standards and poor employment rate. Some similar solutions are also in articles 226 and 227.

This is specific that in the founding treaties there is not anything stated about the innovativeness. The assistance and in consequence the legal regulations have rather ordering character, they support the under developed regions.

In 1986, on the basis of the European Single Act, there was implemented the Economic Community and some numerous changes in the Treaty on European Economic Community. There were introduced a lot of articles and amendments to the treaty. Among others, there was introduced the topic V concerning the coherency of economic and social policies of the Member States. The purpose of that policy is to smooth the existing differences in the development of particular regions. In article 130c and d, it is stated about the changes in funds supporting the regional development, in particular in the European Fund of Regional Development. In turn, in topic VII concerning the environmental protection there is introduced article 130r, in which it is stated the necessity of taking the actions by the community organs and institutions within the balanced protection of environment in individual regions (Barcz, Koliński, 1990: 89). However, the regional policy has the smoothing, not innovative, character.

\subsection{From Maastricht to Lisbon}

In the European Union Treaty from 1992, called the Maastricht Treaty, some statements from the previous treaties were amended. In article 130c, it is appointed the purpose of the European Regional Fund, which is smoothing away the basic regional disproportions in the Community, through participating in the development and structural adjustment of the under developed regions and through transformations of the 
ruined industrial regions. In article 130r it is emphasized the protection of environment in regions, particularly the under developed regions. However, the most important resolution of that Treaty was to create the Committee of Regions in article 198a. The Treaty on European Union was the first treaty where it is stated about the innovativeness. In article 130 it is decided that the Community and the Member States have to assure the necessary conditions for the Community industrial competitiveness. Their activities are aimed towards the better exploitation of the industrial potential of innovative policies, researches and technological development (Barcik, Wentkowski, 2008: 326).

The Amsterdam Treaty (1997) did not introduce any new elements in this framework. In turn the Nice Treaty, in article 137 the Treaty on European Union was amended, there was introduced the notion of innovativeness. The Member States are responsible for the innovative activities. These activities should be undertaken together with the modernization of the educational system, the exchange of information and good practice (Verrilli, 2001: 67).

In the Lisbon Treaty in 2007 in the amended article 3b, there was introduced the information about the European Union, that it acts on the basis of subsidiarity, which means it does not replace the activities of the Member States or the regional authorities. In turn, in article 158, there is stated that the European Union activities are directed towards the rural regions, the industrial regions under the transformations process, the regions suffering from some serious and permanent negative natural and demographic conditions, for example the northernmost regions with very low density of population, the islands regions, transborder and mountain regions.

The innovative activities are treated marginally even in the latest treaties. The legislative procedures are concentrated mainly on the policy of cohesion. The better situation is in the secondary law of the European Union, where numerous legal acts contain the authorizations and liabilities for the regions to introduce the innovative activities, particularly the new technologies and procedures.

\section{Conclusions}

The experiences of the Second World War were the basis of the European integration activities in the $1950 \mathrm{~s}$ of the $20^{\text {th }}$ century. The common activities undertaken then were directed towards the liquidation of the barriers stopping the economic development, particularly standardizing the payments and introducing the principles of public contribution to private entrepreneurs.

Regional policy is one of the most important policies of the European Union. It was initiated in the 1960s. The substantial political decisions were made and the institutional and treaty regulations were introduced over the basic stages of the development of that policy. The purpose of the European Union is to smooth away the existing differences in economic and social development among 271 Union regions. The European Communities in the past, and nowadays the European Union activities, are taken on the basis of subsidiarity. The regional policy is more and more based on the principles of innovative economy.

The analysis of economic and social situation in Europe signalized that there is a need to undertake the activities smoothing away the differentiation in the development of regions. That fact was the basis of the community regional policy. In this way the regions became the subject of the European policy, which is reflected in the Treaty on European Economic Community and in the European Single Act. Whereas in the Treaty on European Union there was created the Committee of Regions, which is the significant institution for the regional policy.

The characteristic feature of the European regional policy, which is noted in the treaties, is implementing the coherency policy. The existing differentiation in the economic and social development of the regions requires undertaking the activities directed towards smoothing these differences. The basic instruments of the coherency policy are the programmes, particularly the European Fund on Regional Development. In some exceptional cases the European Commission can allow to use the public support.

The former European Union regional policy is therefore the passive policy. It is in general based on supporting the underdeveloped regions. Meanwhile, in the regional policy based on the treaty law, there is 
not the element of innovativeness, which should consist in implementing the innovative education, the new procedures of administration activities and implementing the new technologies. Therefore, the European Union should animate the regional authorities to the better, dynamic and innovative activities.

\section{References}

Altshuller, G. S. (1984). Creativity as an Exact Science. The Theory of the Solution of Inventive Problems. CRC Press. Bałaban, A. (1998). Polska koncepcja regionu. In: A. Bałaban, B. Sitek (eds.). Region Europejski a polskie województwo. Toruń: Wit-Graf.

Barcik, J. Wentkowska, A. Prawo Unii Europejskiej z uwzględnieniem Traktatu z Lizbony. Warszawa: C. H. Beck.

Barcz, J., Koliński, A. (1990). Jednolity Akt Europejski. Zagadnienia prawne i instytucjonalne. Warszawa: Polski Instytut Spraw Międzynarodowych.

Ciapała, J. (1998). Zasada subsydiarności w Konstytucji Rzeczpospolitej Polskiej i w Unii Europejskiej. In: A. Bałaban, B. Sitek (eds.). Region Europejski a polskie województwo. Toruń: Wit-Graf.

Doliwa-Klepacki, Z. M. (2005). Integracja Europeejska. Łacznie z uczestnictwem Polski w UE i Konstytucja dla Europy. Białystok: Temida2.

Drucker, P. F. (2004). Natchnienie i fart czyli Innowacja i przedsiębiorczość. Warszawa: Studio EMKA.

Gmyrek, A. M. (2000). Nomenklatura Statystyczna NUTS... Wspólnoty Europejskiej, No. 6.

Kotarba-Kańczugowska, M. (2009). Innowacje pedagogiczne $w$ międzynarodowych raportach edukacyjnych. Warszawa: Wydawnictwo Akademickie ŻAK.

Kuciński, K. (2010). Przedsiębiorczość a rozwój regionalny w Polsce. Warszawa: Difin.

Maczuga, T. (2002). Innowacje w Unii Europejskiej. In: S. Swadźby (ed.). Edukacja i innowacyjność w rozwoju regionów. Tychy: Śląskie Wydawnictwa Naukowe.

Mahdjoubi, D. (1997). Regional Innovation Straegies in the European Community. Website: http://www.ischool.utexas. edu/ darius/12-RIS-EU.pdf [2012-03-12].

Matusiak, T. (2011). Nowa publikacja Eurostatu: regiony pod lupq. Website: http://www.uniaeurop ejska.org/nowa-publikacja-eurostatu-regiony-pod-lupa

Mączyńska, E. (ed.) (2001). Restrukturyzacja przedsiębiorstw w procesie transformacji gospodarki Polskiej, t. 2. Studia wybranych przypadków. Warszawa: Wydawnictwo DiG.

Naruszewicz, S. (2004). Polityka spójności Unii Europejskiej. Wybrane zagadnienia. Warszawa: Difin.

Piecha, K., Kulikowski, M. (2003). Przedsiębiorczość: szansq na sukces rzq̨u, gospodarki, przedsiębiorstw, spoleczeństwa. Warszawa: Instytut Wiedzy.

Puga, D. (2001). European Regional Policies in the light of recent location theories. Journal of Economic Geography, Vol. 18 , No. 1, p. $45-51$.

Roberts, A. (2002). Multilateral Institutions and the Right to Information: Experience in the European Union. European Public Law, No. 8.

Schumpeter, J. A. (1986). History of Economic Analysis. London: Allen\&Unwin Ltd.

Sitek, M. (2011). Samorzady loklane w świetle polityki regionalnej Unii Europejskiej. In: B. Sitek, D. Barańska, K. Naumowicz. Funkcjonowanie samorzqdu terytorialnego w wybranyach państwach UE. Olsztyn: Wydawnictwo UWM.

Steinen, M. (1991). State Aid, Regional Policy and Locational Competition in the European Union. European Urban and Regional Studies, Vol. 4, No. 1, p. 19-31.

Szlachta, J. (2000). Problemy polityki rozwoju regionalnego Polski w warunkach integracji europejskiej. In: J. Hausner, M. Marody (eds.). Jakość zarzadzania: Polska bliżej Unii Europejskiej? EU-monitoring IV. Kraków: Małopolska Szkoła Administracji Publicznej.

Tokarczyk, R. (1989). Wprowadzenie do komparatystyki prawniczej. Lublin: Wydawnictwo Lubelskie.

Verrilli, A. (2001). Il Trattato di Nizza. Napoli: Esselibri S.p.A.

Wilson, Th. M. (2000). Obstacles to European Union regional policy in the Northern Ireland borderlands. Human Organization, Vol. 12, No. 2, p. 33-38.

Woś, B. (2005). Rozwój regionów i polityka regionalna w Unii Europejskiej oraz w Polsce. Wrocław: Politechnika Wrocławska.

Zucca, F. (2001). Autonomie locali e federazione sovranazionale. La battaglia del Conseil des communes et régions d'Europe per l'unità europea. Bolognia: Il Mulino. 


\section{EUROPOS SĄJUNGOS REGIONINES POLITIKOS DINAMIKA}

Magdalena SiteK

Alcide De Gasperi euroregionų ekonomikos universitetas (Lenkija)

\section{Santrauka}

Šio straipsnio tikslas - pateikti Europos Sajungos regioninès politikos formą jos teisini pagrindą ir pagrindines vystymosi perspektyvas. Ši politika tampa vis svarbesnè vykstant decentralizacijai ES valstybėse narėse, vis daugiau valdžios atiduodant regionams. ES regioninè politika yra problemiška sritis, kurią būtina tyrinèti, todèl autorius ES regioninės politikos vystymąsi analizuoja per sutarčių teisès prizmę. Analizè parodè tebesitęsiančio vystymosi mastą. Nepaisant geros teisinès bazès, ES regioninè politika turi būti nuolat derinama, ypač kai kalbama apie subsidijų racionalizavimą. Pasyvi regioninè politika lemia tai, kad remiamos tik ekonomiškai nepakankamai išsivysčiusios teritorijos, todèl būtina diegti programas, kuriomis remiama inovacija, ypač išsivysčiusiuose regionuose, kurie yra visos ES ekonomikos variklis.

PAGRINDINIAI ŽODŽIAI: regionai, sanglaudos politika, struktūrinès programos, inovacine ekonomika, Regionu komitetas.

JEL KODAI: R110, K100 